\title{
Corrigendum
}

\section{Primaries on Demand? Intra-Party Politics and Nominations in Ghana - CORRIGENDUM}

\author{
NAHOMI ICHINO AND NOAH L. NATHAN
}

doi: 10.1017/S0007123412000014, Published online by Cambridge University Press, 6 March 2012.

There are minor errors in six rows of the summary statistics table in the published article (Table 1, page 782). The corrected table here reflects changes to the four variables in the third panel of Table 1, as well as to the mean of the "Area of Constituency" variable and number of observations reported for population density in the first panel. Before the original submission of the manuscript, we made small revisions to the dataset but the summary statistics in these rows in Table 1 had not been updated from the original working paper version to reflect this change. All analyses were conducted on the updated/ corrected data, so this update does not affect any of the results reported in the article (Table 2 or the figures).

TABLE $1 \quad$ Summary Statistics (Corrected)

\begin{tabular}{|c|c|c|c|c|c|}
\hline & Mean & S.D. & Min. & Max. & $N$ \\
\hline \multicolumn{6}{|l|}{ Constituency-Level Variables $^{a, b}$} \\
\hline Ethnic Fractionalization ${ }^{c}$ & 0.414 & 0.201 & 0.058 & 0.821 & 206 \\
\hline Ethnic Polarization $^{d}$ & 0.539 & 0.193 & 0.112 & 0.912 & 206 \\
\hline Ln(Population/sq. km.) & 4.681 & 1.154 & 1.844 & 9.167 & 206 \\
\hline Development Index ${ }^{e}$ & -0.242 & 0.752 & -1.045 & 3.050 & 206 \\
\hline Total Population (non-urban) ${ }^{f}$ & 77,610 & 33,073 & 18,021 & 232,984 & 203 \\
\hline Area of Constituency (sq. km.) & 1137 & 1424 & 16 & 10,831 & 203 \\
\hline Share of population literate in English & 0.463 & 0.189 & 0.061 & 0.845 & 206 \\
\hline $\begin{array}{l}\text { Share of population working in public or } \\
\text { semi-public sector }\end{array}$ & 0.055 & 0.034 & 0.009 & 0.177 & 206 \\
\hline $\begin{array}{l}\text { Share of population residing in town in } \\
\text { which they were born }\end{array}$ & 0.722 & 0.13 & 0.26 & 0.963 & 206 \\
\hline \multicolumn{6}{|l|}{ Constituency/Year-Level Variables } \\
\hline NPP vote share, previous presidenti & 0.471 & 0.224 & 0.01 & 0.895 & 460 \\
\hline NDC vote share, previous presidential election & 0.468 & 0.198 & 0.095 & 0.951 & 460 \\
\hline NPP vote share, previous parliamentary election & 0.438 & 0.218 & 0 & 0.857 & 460 \\
\hline NDC vote share, previous parliamentary election & 0.428 & 0.176 & 0 & 0.909 & 460 \\
\hline Incumbent age (years) & 53.306 & 8.087 & 33 & 80 & 445 \\
\hline Education level of incumbent ${ }^{g}$ & 3.028 & 0.998 & 0 & 5 & 446 \\
\hline Incumbent is minister or deputy minister & 0.233 & & 0 & 1 & 460 \\
\hline Distance $(\mathrm{km})$, MP birthplace to const. centroid & 9.435 & 1.951 & 0.307 & 13.313 & 457 \\
\hline Incumbent seeks nomination & 0.778 & & 0 & 1 & 445 \\
\hline
\end{tabular}


TABLE 1 (Continued)

\begin{tabular}{llllll}
\hline \hline & Mean & S.D. & Min. & Max. & $N$ \\
\hline Constituency/Year/Party-Level Variables & & & & & \\
Primary Election & 0.610 & & 0 & 1 & 461 \\
Number of Aspirants & 2.06 & 1.31 & 1 & 7 & 620 \\
Vetting & 0.05 & & 0 & 1 & 620 \\
Dropout & 0.039 & & 0 & 1 & 619
\end{tabular}

${ }^{a}$ The EC map does not show boundaries for small constituencies in major urban areas; 13 constituencies in Greater Accra, 4 around Takoradi, and 10 in Kumasi are each lumped together, so we generate these variables for 206 areas to cover 230 constituencies.

${ }^{b}$ Calculated from 2000 Population and Housing Census, Ghana Statistical Service.

${ }^{c}$ The fractionalization index is $1-\sum_{i=1}^{N} \pi_{i}^{2}$, where $\pi_{i}$ is the proportion of people in each ethnic group and $N$ is the total number of groups (Montalvo and Reynal-Querol, 'Ethnic Polarization, Potential Conict, and Civil Wars').

${ }^{d}$ The polarization index is $4 * \sum_{i=1}^{N} \pi_{i}^{2}\left(1-\pi_{i}\right)$, where $\pi_{i}$ is the proportion of people in each ethnic group and $N$ is the total number of groups (Montalvo and Reynal-Querol, 'Ethnic Polarization, Potential Conict, and Civil Wars').

${ }^{e}$ The development factor is constructed through a factor analysis of three correlated measures of living conditions: the percentage of homes with electricity, modern sanitation, and running water. ${ }^{f}$ Population totals are aggregated for the three urban areas and cannot be separated out to list by constituency. The total pop. in the urban constituencies is: 1,660,657 for Accra (13); 1,170,270 for Kumasi (10) constituencies; and 326,386 for Takoradi (3).

${ }^{g} 0$ less than secondary, 1 secondary, 2 certificate/post-secondary, 3 bachelors, 4 masters/postgrad, $5 \mathrm{PhD}$ /doctor.

The authors apologise for these errors.

\section{REFERENCE}

Nahomi Ichino and Noah L. Nathan. Primaries on Demand? Intra-Party Politics and Nominations in Ghana. Brit J Polit Sci. Published by Cambridge University Press, 42, 769-791. 